\title{
Author Correction: Macrophage-associated wound healing contributes to African green monkey SIV pathogenesis control
}

Fredrik Barrenas, Kevin Raehtz, Cuiling Xu, Lynn Law, Richard R. Green, Guido Silvestri, Steven E. Bosinger, Andrew Nishida, Qingsheng Li $\mathbb{B}$, Wuxun Lu, Jianshui Zhang, Matthew J. Thomas, Jean Chang, Elise Smith, Jeffrey M. Weiss, Reem A. Dawoud, George H. Richter, Anita Trichel, Dongzhu Ma, Xinxia Peng (D), Jan Komorowski (iD, Cristian Apetrei, Ivona Pandrea \& Michael Gale Jr (iD

Correction to: Nature Communications https://doi.org/10.1038/s41467-019-12987-9, published online 8 November 2019.

The affiliation of Jan Komorowski with the Institute of Computer Science, PAN, Warsaw, Poland, was inadvertently omitted in the original version of this Article. This has now been corrected in both the PDF and HTML versions of the Article.

Published online: 13 December 2019

\footnotetext{
(c) (i) Open Access This article is licensed under a Creative Commons Attribution 4.0 International License, which permits use, sharing, adaptation, distribution and reproduction in any medium or format, as long as you give appropriate credit to the original author(s) and the source, provide a link to the Creative Commons license, and indicate if changes were made. The images or other third party material in this article are included in the article's Creative Commons license, unless indicated otherwise in a credit line to the material. If material is not included in the article's Creative Commons license and your intended use is not permitted by statutory regulation or exceeds the permitted use, you will need to obtain permission directly from the copyright holder. To view a copy of this license, visit http://creativecommons.org/licenses/by/4.0/.
}

(C) The Author(s) 2019 